\title{
Pengaruh model science, environment, technology and society terhadap hasil belajar ilmu pengetahuan alam di sekolah dasar
}

\author{
Ulandari Safitri $^{\left.1^{*}\right)}$, Firman Firman ${ }^{2}$, Desyandri Desyandri ${ }^{3}$ \\ ${ }^{123}$ Universitas Negeri Padang
}

\begin{tabular}{l} 
Article Info \\
\hline Article history: \\
Received Jun $12^{\text {th }}, 201 x$ \\
Revised Aug $20^{\text {th }}, 201 x$ \\
Accepted Aug $26^{\text {th }}, 201 x$ \\
\hline
\end{tabular}

\section{Keyword:}

Model pembelajaran SETS Ilmu pengetahuan alam Hasil belajar.

\begin{abstract}
ABSTRAK
Penelitian ini bertujuan untuk mengetahui pengaruh penggunaan model Science, Environment, Technology and Society (SETS) terhadap hasil belajar. jenis penelitian yang digunakan adalah eksperimen dengan rancangan Design Static-Group Comparisson. Populasi pada penelitian ini adalah seluruh siswa kelas di SD Istiqamah Sicincin sekaligus menjadi sampel. Instrumen penelitian ini adalah tes sedangkan data penelitian ini adalah hasil tes dan data observasi pelaksanaan penelitian yang diamati oleh observer. Hasil akhir di peroleh kelas eksperimen 77,92 dan kelas kontrol 63,13. Hasil uji t didapatkan thitung adalah 4,87, dan t-tabel dengan derajat kebebasan dk 48 dari tabel-t (0.950)(48)=2,012.. Dapat disimpulkan model SETS berpengaruh positif terhadap hasil belajar IPA.
\end{abstract}

\section{Corresponding Author:}

Ulandari Safitri,

Universitas Negeri Padang

Email: ulandarisafitri30@gmail.com :

\section{Pendahuluan}

Menurut H. Horne, pendidikan adalah proses yang terus menerus (abadi) dari penyesuaian yang lebih tinggi bagi makhluk manusia yang telah berkembang secara fisik dan mental, yang bebas dan sadar kepada tuhan, seperti termanifestasi (terwujud) dalam alam sekitar intelektual, emosional dan kemanusiaan dari manusia. Setiap negara maju tidak akan pernah terlepas dengan dunia pendidikan. Semakin tinggi kualitas pendidikan suatu negara, maka semakin tinggi pula kualitas sumber daya manusia yang dapat memajukan dan mengharumkan negaranya. meskipun begitu banyak sekali ditemukan masalah-masalah didalam pendidikan diantaranya guru yang kurang bisa menerapkan model pembelajaran yang inovatif disetiap pembelajaran sehingga berpengaruh terhadap hasil belajar siswa. Apabila semua masalah dalam pendidikan di indonesia dapat teratasi dengan baik dan bijaksana maka mutu pendidikan yang baik akan diperoleh dengan sendirinya. Dunia pendidikan mengenal kurikulum 2013 yang berlangsung pada saat ini, kurikulum 2013 yang diterapkan sekarang sangat banyak memuat harap yang bertujuan untuk perbaikan pendidikan di indonesia. Salah satunya adalah dengan perbaikan perangkat pembelajaran dimana didalam kurikulum tersebut membuat beberapa aturan yang harus menjadi acuan kita dalam membuat berbagai perangkat pembelajaran untuk kepentingan pendidikan. Baik semua itu dianalisis dari segi RPP, model, media yang digunakan serta pendekatan apa yang akan dipergunakan, hal itu tidak luput dari aturan pelaksanaan kurikulum 2013 tersebut.

Proses pendidikan yang terjadi disekolah dapat diwujudkan melalui kegiatan pembelajaran yang terjadi di kelas. Kegiatan pembelajaran adalah kegiatan yang terjadi di kelas dengan melibatkan peran pendidik beserta peserta didik. Peran guru di sini adalah dengan memfasilitasi siswa untuk mencari konsep yang diperlukan dalam memecahkan masalah yang dialaminya, sedangkan peran siswa di sini adalah dengan menyelidiki dan 
mengidentifikasi masalah yang dihadapinya untuk mencari sendiri konsep yang diperlukan dalam memecahkan masalah yang dihadapinya sehingga menimbulkan hubungan positif antara pendidik dan peserta didik selama proses pembelajaran di kelas.

Pembelajaran yang terjadi di sekolah dasar ada berbagai macam, diantaranya adalah pembelajaran IPA. Pembelajaran IPA adalah pembelajaran yang lebih banyak membahas peristiwa yang terjadi dialam dan hal itu didapatkan dari berbagai pengalaman dan serangkaian proses ilmiah. Dengan demikian diharapkan pembelajaran sains dapat membuat siswa terbiasa dalam mengatasi permasalahan yang dihadapinya di kehidupan sehari-hari dengan melakukan serangkaian aktivitas ilmiah berkaitan dengan lingkungan sosial dan alam yang ada di sekitarnya. Keterampilan tersebut diperlukan agar peserta didik dapat memiliki kemampuan memperoleh, mengelola, dan memanfaatkan informasi dengan baik (Ahmad, Kenedi, \& Helsa, 2018). Hakekat dari pembelajaran IPA ini adalah mengembangkan pemahaman peserta didik tentang alam, mengembangkan keterampilan yang diperlukan untuk memperoleh atau mengembangkan pengetahuan yang baru, dan mengembangkan sikap positif pada peserta didik, (Jannatin 'Ardhuha, Lalu Rudyat Telly Savalas2, \&Nurwahidah, 2020). Proses pembelajaran IPA hendaknya dapat merujuk pada tujuan-tujuan pembelajaran IPA(Siti Nur Azizah Puji Ayu Lestar, Asep Kurnia Jayadinata, Ani Nur Aeni, 2017).

Namun dari hasil observasi yang di peroleh di SD Istiqamah Sicincin di kelas VA dan VB di SD Istiqamah Sicincin, pada tanggal 7-9 Februari 2020. Peneliti memaparkan beberapa masalah yaitu: Pertama, dalam proses pembelajaran siswa tidak didorong untuk menanamkan konsep IPA dalam kehidupan sehari-hari. Kedua, peserta didik menjadi cawan dalam menerima pengetahuan atau informasi berkaitan tentang pembelajaran, dan semua ini tidak sesuai dengan harapan yang di harapkan yaitu proses pembelajaran dapat memberikan perpusatan kepada peserta didik (student centered). Ketiga, saat pembelajaran berlangsung, siswa tidak dapat mengaitkan pembelajaran ipa dengan kejadian yang ada atau mengaitkan dengan pembelajaran lainnya. Keempat, sumber belajar yang tidak memadai sehingga membuat siswa tidak dapat membangun kreativitas berpikirnya, dampaknya banyak siswa kurang berpartisipasi dalam pembelajaran. Kelima hasil belajar siswa yang rendah.

Berdasarkan Paparan masalah diatas, peneliti bertujuan untuk menganalisis pengaruh penggunaan model Science, Environment, Technology and Society (SETS) memiliki pengaruh positif terhadap hasil belajar IPA di SD. Secara teoretis penelitian ini mempunyai harapan untuk peningkatan proses belajar siswa di sekolah dasar khususnya pada pembelajaran IPA dengan materi pembelajaran kalor dapat mengubah suhu benda yang menggunakan model Science, Environment, Technology and Society (SETS). Masalah.kontekstual.yang diberikan mampu mendorong siswa.untuk menemukan hubungan suatu materi yang dipelajari.dengan situasi.dunia nyata (Desyandri, Yesya, \& Alwi, 2018). Selain itu juga dapat menumbuhkan kreativitas siswa dalam proses pembelajaran disekolah dasar khususnya.

\section{Metode}

Penelitian ini menggunakan metode penelitian eksperimen kuasi. Risda Amini dan A. Munandar (2010) menyatakan bahwa quasy eksperimentdesign adalah desain penelitian yang menggunakan dua kelas sampel yaitu kelas eksperimen dan kelas kontrol dimana akan diberi perlakuan yang berbeda dengan materi atau bahan ajar yang sama. Eksperimen merupakan sebuah penelitian yang memerlukan kelas eksperimen dan kelas kontrol, tetapi tidak memungkinkan diadakannya pengambilan subjek penelitian secara acak dari populasi yang ada (Ni Md Putri Dwi Apriliani, I Md Citra Wibawa, \& Ni Wyn Rati, 2019). Rancangan penelitian yang digunakan pada penelitian ini adalah desain Static Group Comparison yang sudah dilaksanakan pada kelas V di Sekolah Dasar Istiqamah Sicincin. Pada semester II tahun 2019/2020. Yang dipilih peneliti sebagai Populasi adalah seluruh siswa kelas V SD Istiqamah Sicincin. Berjumlah 53 orang diantaranya 25 di kelas VA dan 26 di kelas VB SD Istiqamah Sicincin. Dan Seluruh populasi dijadikan sampel. Kelas eksperimen diberikan model pembelajaran Science, Environment, Technology and Society (SETS), sedangkan kelas kontrol diberikan pembelajaran konvensional. Setelah diberikan perlakuan pada masing-masing kelas sampel, kemudian diberikan postest yang sama pada kedua kelas tersebut.

\section{Hasil dan Pembahasan}

Pembelajaran di kelas eksperimen dilakukan sesuai dengan langkah-langkah Science, Environment, Technology and Society (SETS). Pelaksanaan pembelajaran di kelas kontrol, di awasi oleh obsever mulai dari awal kegiatan pembelajaran sampai berakhirnya proses pembelajaran. Pembelajaran adalah sebuah proses perubahan tingkah laku dari hasil interaksi munusia dengan lingkungannya supaya kebutuhan hidup terpenuhi (Frandy Pratama, Firman,\& Neviyarni, 2019). Penelitian kelas kontrol dilakukan sesuai dengan langkah- 
langkah pembelajaran konvensional, yang didukung dengan penggunaan media pembelajaran berupa gambar. Proses pembelajaran pada kelas kontrol mulai dari awal kegiatan proses pembelajaran sampai akhir proses pembelajaran dinilai oleh obsever, untuk melihat apakah langkah-langkah dari pembelajaran konvensional dilakukan sesuai dengan apa yang telah direncanakan sebelumnya.

Data hasil proses pembelajaran di kelas eksperimen dengan model Science, Environment, Technology and Society (SETS) beserta datanya posttest kedua di kelas kontrol dengan model konvensional beserta datanya, hasil belajar diperoleh melalui posttet yang dilaksanakan setelah proses pembelajaran. Tes akhir (posttest) dilaksanakan di kelas VA pada tanggal 28 Maret 2020 dengan nilai rata-rata 77,92 dari 26 orang peserta didik. Pada hari yang sama di kelas VB kontrol diberikan tes akhir (posttest), diperoleh nilai rata-rata 63,13 dari 24 orang peserta didik. Data hasil belajar untuk masing-masing peserta didik pada kelas eksperimen dan kelas kontrol yang terlihat pada tabel di bawah ini.

Tabel 1. Nilai rata-rata tes akhir kelas sampel

\begin{tabular}{lcc}
\multicolumn{1}{c}{ Kelas } & Jumlah Siswa & Rata-Rata Tes Akhir (Posttest) \\
\hline Eksperimen & 26 & 77.92 \\
\hline Kontrol & 24 & 63,13 \\
\hline
\end{tabular}

Pada kelas eksperimen rata-rata tes akhir dari 26 peserta didik adalah sebesar 77,92 dan rata-rata tes akhir kelas kontrol dari 24 peserta didik sebesar 63,13. Selisih rata-rata tes akhir antara kedua kelas sampel adalah 14.79 , terlihat bahwa rata-rata tes akhir kelas eksperimen lebih tinggi daripada rata-rata tes akhir kelas kontrol yang terlihat pada grafik dibawah ini. Hasil dari perhitungan nilai rata-rata, simpangan baku (S), dan varians (S2) iniposttest (tes akhir) pada kelas sampel. Nilai rata-rata, simpangan baku, dan varians kelas sampel tergambar dalam tabel 12 .

Tabel 2. Nilai rata-rata, simpangan baku, varians kelas sampel (Posttest)

\begin{tabular}{ccccccc}
\hline No & Kelas & $\mathbf{N}$ & $\overline{\mathbf{X}}$ & $\mathbf{S}$ & $\mathbf{S}^{2}$ & Ket \\
\hline $\mathbf{1}$ & Eksperimen & 26 & 77.92 & $11,93$. & 142.39 & Posttest \\
\hline $\mathbf{2}$ & Kontrol & 24 & 63,13 & 11.41 & 130.11 & Posttest \\
\hline
\end{tabular}

Nilai Posttest kedua kelas sampel

Pada tabel di atas tergambar bahwa nilai rata-rata tes akhir (posttest) kelas eksperimen adalah 77.92dan nilai rata-rata tes akhir (posttest) kelas kontrol adalah 63.13. Tergambar bahwa nilai rata-rata pada kelas kontrol lebih rendah dari pada nilai rata-rata kelas eksperimen. Dengan selisih angka 14,79. Hasil pembelajaran model Science, Environment, Technology and Society (SETS) terhadap hasil belajar IPA di Kelas V SD Istiqamah Sicincin lebih tinggi nilai rata-ratanya dibandingkan dengan kelas kontrol dengan pembelajaran konvensional.

Data yang diolah dalam penelitian ini hanya pada dimensi pengetahuan. Analisis data dilakukan sebelum mengambil kesimpulan dari hasil penelitian, dan melalui uji hipotesis statistik untuk mengukur dimensi pengetahuan. Langkah-langkah yang dilakukan dalam uji hipotesis ini adalah melakukan uji persyaratan analisis yaitu uji normalitas dan uji homogenitas kedua kelas sampel terlebih dahulu.

Pengujian normalitas ini digunakan uji Liliefors. Data yang digunakan dalam uji Liliefors dengan menggunakan data mentah yang didapat dari posttest untuk kedua kelas sampel yaitu kelas eksperimen dan kontrol. ini hasil yang diperoleh dari perhitungan tersebut.

Tabel 3. Uji normalitas kelas sampel

\begin{tabular}{cccccc}
\hline No & Kelas & $\mathbf{N}$ & $\mathbf{L}_{\text {hitung }}$ & $\mathbf{L}_{\text {tabel }}$ & Keterangan \\
\hline $\mathbf{1}$ & Eksperimen & 26 & 0,1079 & 0,171 & Normal \\
\hline $\mathbf{2}$ & Kontrol & 24 & 0,1249 & 0,173 & Normal \\
\hline
\end{tabular}

Nilai $\mathrm{L}_{\text {hitung }}$ dan $\mathrm{L}_{\text {tabel }}$ kedua kelas kontrol

Uji normalitas untuk penelitian ini harga Lhitung (Lh) dan Ltabel (Lt) diambil dari taraf nyata 0,05 jika Lhitung (Lh) < Ltabel (Lt) maka data berdistribusi normal. Sebaliknya jika Lhitung (Lh) > Ltabel (Lt) maka data tidak berdistribusi normal. Pada tabel tersebut terlihat bahwa nilai Lhitung (Lh) kedua kelas lebih kecil dari Ltabel sehingga kedua kelas tersebut berdistribusi normal. 
Uji homogenitas berguna untuk menentukan apakah kedua kelompok data mempunyai varians yang homogen atau tidak. Pengujian homogenitas terhadap kedua data menggunakan uji $\mathrm{F}$ yang terlihat pada lampiran 24. Berikut adalah hasilnya.

Tabel 4. Hasil uji homogenitas kedua kelas sampel

\begin{tabular}{|c|c|c|c|c|c|c|}
\hline No & Kelas & $\mathbf{N}$ & $\mathbf{S}^{2}$ & $\mathbf{F}_{\text {tabel }}$ & $\mathbf{F}_{\text {hitung }}$ & Ket \\
\hline 1 & Eksperimen & 26 & 142,39 & \multirow{2}{*}{2,02} & \multirow{2}{*}{1,09} & \multirow{2}{*}{ Homogen } \\
\hline 2 & Kontrol & 24 & 130,11 & & & \\
\hline
\end{tabular}

Dari uji homogenitas ini juga ditentukan harga Fhitung $(\mathrm{Fh})$ dan Ftabel $(\mathrm{Ft})$ jika Fhitung $(\mathrm{Fh})<$ Ftabel $(\mathrm{Ft})$ maka kedua data memiliki varians homogen. Sebaliknya jika Fhitung $(\mathrm{Fh})>$ Ftabel $(\mathrm{Ft})$ maka kedua data tidak memliki varians yang homogen. Pada tabel tersebut terihat bahwa nilai Fhitung (Fh) kedua kelas lebih kecil dari Ftabel (Ft) sehingga kedua data memiliki varians yang homogen. Berdasarkan uji statistik, diperoleh kedua data berdistibusi normal dan homogen. Oleh karena itu pengujian hipotesis dapat dilakukan dengan mengunakan uji t.

Tabel 5. Hasil penghitungan uji $\mathrm{t}$

\begin{tabular}{ccc}
\hline Taraf Signifkansi & T hitung & T tabel \\
\hline $\mathbf{5 \%}$ & 4,87 & 2,012 \\
\hline
\end{tabular}

. Berdasarkan perhitungan tersebut, diperoleh bahwa nilai t hitung 4,87. Nilai $t$ table pada taraf signifikansi $5 \%$ adalah 2,012. Kriteria penerimaan hipotesis berdasrkan hasil uji hipotesis menyatakan $\mathrm{t}$ hitung $>\mathrm{t}$ tabel, artinya peneilitian ini menolak H0 dan menerima Ha.

$\mathrm{H}_{\mathrm{a}}$ : Model Science, Environment, Technology and Society (SETS) lebih baik pengaruhnya dari pada konvensional terhadap hasil belajar IPA kelas V SD Istiqamah Sicincin.

Berdasarkan uji hipotesa hasil belajar dimensi pengetahuan model Science, Environment, Technology and Society (SETS) berpengaruh penting terhadap hasil belajar IPA di kelas V SD Istiqomah sicincin. Rata-rata tes akhir kelas eksperimen dengan model Science, Environment, Technology and Society (SETS) adalah 77,92 dan rata-rata tes akhir kelas kontrol dengan pembelajaran konvensional 63,13. Hasil uji t didapatkan $t$ hitung adalah 2,89. dan $\mathrm{t}$ tabel dengan derajat kebebasan dk 48 dari tabel $\mathrm{t}(0.975)(43)=2,012$. Dapat dikatakan model Science, Environment, Technology and Society (SETS) lebih baik digunakan di sekolah dari pada model konvensional.

Model Science, Environment, Technology and Society (SETS) lebih baik digunakan daripada konvensional, karena dengan menggunakan model Science, Environment, Technology and Society (SETS) dapat menciptakan situsi belajar mengajar yang kondusif. pemahaman konsep yang baik dalam pembelajaran akan melahirkan pemahan konsep yang baik dan siswa juga mampu mengaitkan pengetahuan sains yang diperoleh dengan pengetahuan lainnya sehingga pemahaman siswa semakin meningkat dan lebih luas cakupannya.

\section{Simpulan}

Berdasarkan hasil analisis disimpulkan bahwa lebih baik pengaruhna terhadap hasil belajar IPA siswa yang diberi perlakuan model pembelajaran Science, Environment, Technology and Society (SETS) dari pada siswa yang diberi perlakuan pembelajaran konvensional di siswa kelas V SD Istiqamah Sicincin Kabupaten Padang Pariaman. Hal ini dapat dilihat dari analisis uji-t data postest kelas eksperimen dan kelas kontrol. Hasil postest kelas eksperimen dan kelas kontrol diperoleh nilai $t$ hitung sebesar 4,87 sedangkan nilai $t$ tabel sebesar 2,012 pada, dengan taraf signifikan 0,05 . Berdasarkan perbandingan diatas, ternyata nilai thitung lebih besar dari nilai ttabel (thitung $>$ ttabel).

\section{Referensi}

Ahmad, S., Kenedi, A. K., \& Helsa, Y. (2018). The instruments of higher order thinking skills. 
Al-Tabany, Trianto, Ibnu Badar. (2014). Mendesain Model Pembelajaran Inovatif, Progresif, dan Kontekstual: Konsep, Landasan, dan Implementasinya pada Kurikulum 2013 (Kurikulum Tematik Integratif/KTI. Jakarta: Kencana.

Amini, R., \& Munandar, A. (2010). Pengaruh model pembelajaran pendidikan lingkungann berbasis outdoor terhadap penguasaan konsep pendidikan lingkungan bagi calon guru sekolah dasar. Jurnal Penelitian Pendidikan.

Arikunto, Suharsimi. (2016). Prosedur penelitian suatu pendekatan pratik. Jakarta: Bumi Aksara.

Arikunto, Suharsimi. (2015). Dasar-Dasar Evaluasi Pendidikan. Jakarta: Bumi Aksara.

Arikunto, Suharsimi. (2013). Prosedur penelitian suatu pendekatan pratik. Jakarta: Rineka Cipta.

Ardhuha, J., Savalas, L. R. T., \& Nurwahidah, N. (2020). Pendampingan Pembelajaran IPA Bagi Peserta Didik SDN 38 Ampenan Untuk Materi Bunyi, Cahaya, Listrik dan Magnet. Jurnal Pengabdian Masyarakat Sains Indonesia. https://doi.org/10.29303/jpmsi.v2i2.43

Dantes. 2012. Metode Penelitian. Yogyakarta: Andi.

Desyandri, Yesya, D. P., \& Alwi, E. (2018).Pengaruh Penggunaan Model Contextual Teaching and Learning (CTL) dalam Pembelajaran PKn di Sekolah Dasar.E-Journal Inovasi Pembelajaran SD, 6(1), 1-10.

Dwi Apriliani, N. M. P., Wibawa, I. M. C., \& Rati, N. W. (2019). Pengaruh Model Pembelajaran Inkuiri Terbimbing Terhadap Hasil Belajar IPA. Jurnal Penelitian Dan Pengembangan Pendidikan. https://doi.org/10.23887/jppp.v3i2.17390

Istarani dan Muhammad Ridwan. (2015).50 Tipe Strategi dan Teknik Pembelajaran Kooperatif. Medan: Media Persada.

Lestari, Siti Nur Azizah Puji Ayu , Jayadinata, Asep Kurni, Aeni, Ani Nur. (2017) Meningkatkan Keterampilan Proses Sains Siswa Pada Materi Sifat-Sifat Cahaya Melalui Pembelajaran Inkuiri. Jurnal Pena Ilmiah. https://doi.org/10.17509/jpi.v2i1.10051

Mahdian, M., Almubarak, A., \& Hikmah, N. (2019). Implementasi Model Pembelajaran Icare (IntroductionConnect-Apply-Reflect-Extend) Terhadap Keterampilan Proses Sains Pada Materi Larutan Elektrolit Dan Non Elektrolit. Jurnal Penelitian Pendidikan IPA. https://doi.org/10.29303/jppipa.v5i1.184

Majid, Abdul. (2015). Strategi Pembelajaran. Bandung. Remaja Rosdakarya.

Nasution. (2015). Berbagai Pendekatan dalam Proses Belajar \& Mengajar. Jakarta:Bumi Aksara

Ngalimun. (2014). Strategi dan Model Pembelajaran. Yogyakarta: Aswaja Pressindo

Permendikbud Nomor.103. (2014). Pembelajaran Pendidikan Dasar dan Menengah. Jakarta:Depdikbud.

Permendikbud. 66. (2013). Standar Penilaian Pendidikan Dasar Dan Menengah. Jakarta. Depdikbud

Pratama, F., Firman, F., \& Neviyarni, N. (2019). Pengaruh Motivasi Belajar Siswa Terhadap Hasil Belajar Ipa Di Sekolah Dasar. Edukatif: Jurnal Ilmu Pendidikan. Https://Doi.Org/10.31004/Edukatif.V1i3.63

Riduwan. (2006). Belajar Mudah Penelitian Untuk Guru-Karyawan dan peneliti pemula. Bandung:Alfabeta.

Rusman. (2011). Model-Model Pembelajaran Mengembankan Profesionalisme Guru. Jakarta: Raja Grafindo Persada.

Shoimin, Aris. (2014). 68 Model Pembelajaran Inovatif dalam Kurikulum 2013. Yogyakarta. Ar-Ruzz Media.

Slameto. (2015). Belajar dan Faktor-Faktor Yang Mempengaruhinya. Jakarta: Rineka Cipta.

Sudjana, Nana. (2012). Penilain Hasil Proses Belajar Mengajar. Bandung: Remaja Rosdakarya.

Sugiyono. (2015). Metode Penelitian Pendidikan Pendekatan Kualitatif, Kuantitatif dan R\&D. Bandung: Alfabeta.

Susanto. (2013). Teori Belajar dan Pembelajaran di Sekolah Dasar. Jakarta: Kencana Prenada Media Group.

Sumantri. (2015). Strategi Pembelajaran Teori dan Praktik Di Tingkat Pendidikan Dasar. Jakarta: Raja Grafindo Persada.

Suryabrata, Sumadi. (2013). Metodologi Penelitian. Jakarta: PT Rajagrafindo Persada.

Supraptayana. (2014). Pengaruh Penggunaan PBL pada Aktifitas Belajar Dan Hasil Belajar Siswa Pada Mata Pelajaran Pendidikan Kewarganegaraan Kelas IV SDN 1 Jiningdalem. Bali.

Trianto. (2012). Model Pembelajaran Terpadu Konsep, Strategi, dan implementasi dalam Kurikulum Tingkat Satuan Pendididkan (KTSP). Jakarta: Bumi Aksara.

Yusuf, Muri. (2016). Metode Penelitian Kuantitatif, Kualitatif \& Penelitian Gabungan. Jakarta: Kencana. 